University of Nebraska - Lincoln

DigitalCommons@University of Nebraska - Lincoln

Publications, Agencies and Staff of the U.S.

Department of Commerce

U.S. Department of Commerce

2010

\title{
Validation of a homologous canine relaxin radioimmunoassay and application with pregnant and non-pregnant Northern fur seals (Callorhinus ursinus)
}

\author{
Don R. Bergfelt \\ US Environmental Protection Agency \\ Bernard G. Steinetz \\ New York University School of Medicine \\ J. Lawrence Dunn \\ Mystic Aquarium and Institute for Exploration \\ Shannon Atkinson \\ University of Alaska Fairbanks \\ J. Ward Testa \\ National Marine Mammal Laboratory \\ See next page for additional authors \\ Follow this and additional works at: https://digitalcommons.unl.edu/usdeptcommercepub \\ Part of the Environmental Sciences Commons
}

Bergfelt, Don R.; Steinetz, Bernard G.; Dunn, J. Lawrence; Atkinson, Shannon; Testa, J. Ward; and Adams, Gregg P., "Validation of a homologous canine relaxin radioimmunoassay and application with pregnant and non-pregnant Northern fur seals (Callorhinus ursinus)" (2010). Publications, Agencies and Staff of the U.S. Department of Commerce. 191.

https://digitalcommons.unl.edu/usdeptcommercepub/191

This Article is brought to you for free and open access by the U.S. Department of Commerce at DigitalCommons@University of Nebraska - Lincoln. It has been accepted for inclusion in Publications, Agencies and Staff of the U.S. Department of Commerce by an authorized administrator of DigitalCommons@University of Nebraska - Lincoln. 


\section{Authors}

Don R. Bergfelt, Bernard G. Steinetz, J. Lawrence Dunn, Shannon Atkinson, J. Ward Testa, and Gregg P. Adams 


\title{
Validation of a homologous canine relaxin radioimmunoassay and application with pregnant and non-pregnant Northern fur seals (Callorhinus ursinus) is $^{\text {th }}$
}

\author{
Don R. Bergfelt ${ }^{\mathrm{a}, *}$, Bernard G. Steinetz ${ }^{\mathrm{b}}$, J. Lawrence Dunn ${ }^{\mathrm{c}}$, Shannon Atkinson ${ }^{\mathrm{d}, \mathrm{e}}$, J. Ward Testa ${ }^{\mathrm{f}}$, \\ Gregg P. Adams ${ }^{g}$ \\ a US Environmental Protection Agency, Washington, DC 20460, USA \\ ${ }^{\mathrm{b}}$ New York University School of Medicine, Tuxedo, NY 10987, USA \\ ${ }^{\mathrm{c}}$ Mystic Aquarium and Institute for Exploration, Mystic, CT 06355, USA \\ d University of Alaska Fairbanks, Juneau, AK 99801, USA \\ e Alaska SeaLife Center, Seward, AK 99664, USA \\ ${ }^{\mathrm{f}}$ National Marine Mammal Laboratory, Anchorage, AK 99508, USA \\ ${ }^{\mathrm{g}}$ University of Saskatchewan, Saskatoon, SK S7N 5B4, Canada
}

\section{A R T I C L E I N F O}

\section{Article history:}

Received 21 April 2009

Revised 25 May 2009

Accepted 27 May 2009

Available online 6 June 2009

Keywords:

Northern fur seals (Callorhinus ursinus)

Relaxin

Radioimmunoassay

Pregnancy

\begin{abstract}
A B S T R A C T
The primary objectives of this study were to validate a canine relaxin RIA for use in otariids and phocids and consider practical applications. For 6 captive Northern fur seal females, serum samples were grouped and examined according to pregnancy $(n=13)$, post-partum $(n=8)$ and non-pregnancy $(n=6)$, and, for 2 captive Northern fur seal males, serum samples were grouped and examined together regardless of age ( 2 mo-15 yrs, $n=6$ ). Placental tissue was available for examination from one Northern fur seal, Steller sea lion and harbor seal. The validation process involved several steps using an acid-acetone extraction process to isolate a relaxin-containing fraction in pools of serum from each group of fur seals and placental tissue from each seal species. A relaxin-like substance was detected in extracts of pregnant, non-pregnant and male serum and placental tissue in a dose-responsive manner as increasing volumes of respective extracts or amounts of canine relaxin were introduced into the assay. In raw serum samples, mean immuno-reactive relaxin concentrations were higher $(P<0.05)$ during pregnancy than post-partum and non-pregnancy, and lower $(P<0.05)$ in male than female fur seals. During pregnancy, mean serum concentrations of relaxin progressively increased $(P<0.05)$ over Months $4-10$ and, in serial samples collected from the same fur seals before and after parturition, mean concentrations were higher $(P<0.06)$ pre-partum than post-partum. In conclusion, validation of a homologous canine relaxin RIA for use in otariids and phocids resulted in the discovery of a relaxin-like substance in extracted and raw serum and placental tissue from Northern fur seals, a Steller sea lion and harbor seal. Distinctly higher immuno-reactive concentrations during pregnancy indicated the potential for relaxin to serve as a hormonal marker to differentiate between pregnant and non-pregnant or pseudopregnant pinnipeds.
\end{abstract}

Published by Elsevier Inc.

\section{Introduction}

In 1988 the US National Marine Fisheries Service (NMFS) declared the stock of Eastern Pacific Northern fur seals (Callorhinus ursinus) of the Pribilof Islands (St Paul and St George), Alaska as depleted under the Marine Mammal Protection Act (NMFS, 2007). The basis for the population decline is not fully known but likely involves a combination of natural (e.g., disease, predator-prey) and human-related (e.g., sea debris, endocrine disruptors) factors that have had a direct and indirect effect on reproduction. Our cur-

\footnotetext{
The views expressed in this article are those of the authors and do not necessarily reflect the views or policies of the USEPA or other institutions represented by the authors.

* Corresponding author. Fax: +1 2025648483.

E-mail address: bergfelt.don@epa.gov (D.R. Bergfelt).
}

rent understanding of reproductive physiology in fur seals is rudimentary since most of what is known comes from a few early studies where seals were captured at sea and on land at different times during their reproductive cycles, euthanized and necropsied (reviews, Daniel, 1981; Boyd, 1991; Atkinson, 1997; Boyd et al., 1999). Apart from terminal studies, there are only a few later studies that have collected reproductive data in a longitudinal manner in other otariids (Gales et al., 1997; Greig et al., 2007; VillegasAmtmann et al., 2009). To clarify the nature of the population decline and for planning mitigation strategies in Northern fur seals and other threatened otariid and phocid populations, there is a need to establish a contemporary and comprehensive data base of pinniped reproductive physiology using nonlethal techniques.

Implantation and development of the placenta is a pivotal event in the survival of the early embryo, yet it is one of the least understood aspects of reproduction in mammals (review, Cross et al., 1994). 
Implantation failure accounts for almost $80 \%$ of early embryonic loss that occurs in domestic animals (Roberts et al., 1990, 1992; King, 1991). Although the pregnancy loss rate in Northern fur seals preand post-embryonic diapause is not known, approximately $88 \%$ of 603 multiparous females collected at sea and examined post-mortem had evidence of implantation of which approximately $1.6 \%$ of the pregnant females apparently aborted a fetus (York and Scheffer, 1997). For the remaining fur seals, implantation either failed (i.e., no evidence of implantation) or the early embryo was overlooked.

Relaxin is a 6-kDa polypeptide related to the insulin family of hormones and growth factors (review, Park et al., 2005). In most species studied, the embryo/feto-placental unit is the greatest source of relaxin production. In some species (reviews, Hayes, 2004; Sherwood, 2004; Park et al., 2005), relaxin is also produced to a lesser extent by other reproductive organs in females (e.g., ovaries, uterus) and males (e.g., testes, prostate) as well as in non-reproductive organs (e.g., heart, kidneys). Relaxin is well known to have an effect in humans and laboratory and domestic animals during late pregnancy as a hormone responsible for relaxation of the cervix and pelvic ligaments in association with parturition (review, Dschietzig and Stangl, 2003). Less well known is the role relaxin plays during early pregnancy when non-placental sources of relaxin signal remodeling of the uterine stroma and vasculature and the production of factors that promote trophoblast adherence to and invasion of the endometrium (Dschietzig and Stangl, 2003; Hayes, 2004; Sherwood, 2004; Park et al., 2005). In this regard, disruption of relaxin production during early pregnancy has been associated with embryo/fetal loss in humans and primates (Stewart et al., 1993; Einspanier et al., 1999).

In veterinary medicine, immunoassay and detection of elevated systemic relaxin concentrations is a diagnostic indicator of pregnancy and differential measure to distinguish between pregnant and pseudopregnant dogs (Steinetz et al., 1989) since progesterone concentrations are not distinctly different between pregnant and non-pregnant bitches (review, Johnston et al., 2001). Reportedly (Sherwood, 2004), there has been limited ( $<76 \%)$ evolutionary conservation of the amino acid sequence of relaxin among the more than 25 species in which the sequence of relaxin is known. Nevertheless, canine as well as porcine and equine radioimmunoassays (RIA) have been used to detect immuno-reactive relaxin in association with pregnancy in the serum of spotted hyenas (Steinetz et al., 1997), llamas (Bravo et al., 1996), rhinoceroses and elephants (Steinetz et al., 2005), in the plasma of coyotes (Carlson and Gese, 2007), and in the serum and urine of domestic and non-domestic cats (Stewart and Stabenfeldt, 1985; de Haas van Dorsser et al., 2006). Immunoreactive relaxin has also been detected in placental tissue of the spotted hyena (Steinetz et al., 1997). Considering these results, relaxin has been proposed as a potential hormonal marker of pregnancy in wild animal species (reviews, Steinetz et al., 2005, 2009).

Anatomically, the chorio-allantoic placenta of pinnipeds is comparable to many other carnivores (Harrison et al., 1952). For example, canids and pinnipeds have zonary, endothelio-chorial placentation (Craig, 1964; Miglino et al., 2006). Considering the evolutionary proximity of these species, a previously validated canine relaxin RIA (Steinetz et al., 1996) was chosen to attempt validation for use with pinnipeds and investigate the potential of relaxin to serve as a hormonal marker of pregnancy in otariids and phocids. It is expected that a relaxin RIA for use in pinnipeds will provide a nonlethal and repeatable approach to study the basic physiology of uterine-conceptus-ovarian interactions during the peri-implantation period at the end of embryonic diapause and serve as a diagnostic tool for detecting pregnancy status in captive and free-ranging otariids and phocids for conservation and reproductive management purposes.

The primary objectives of this study were to validate a canine relaxin RIA for use with serum from Northern fur seals, test the hypothesis that immuno-reactive relaxin concentrations are higher in pregnant than in non-pregnant fur seals and consider practical applications. Secondarily, placental tissue samples from a Northern fur seal, Steller sea lion (Eumetopias jubatus) and harbor seal (Phoca vitulina) were included in the study, in part, to supplement the assay validation process and provide preliminary information on the source of relaxin in otariids and phocids.

\section{Materials and methods}

\subsection{Animals and serum samples}

Northern fur seals from which the serum samples were collected and used in the present study were in residence at Mystic Aquarium (Mystic, CT, USA). All 6 females were captured and moved from St Paul Island, Alaska as young adults in the summer of 1984, whereas the 2 males were born in captivity in 1988 and 2003. Seals were housed and fed in compliance with the US Animal Welfare Act and standard aquarium management practices for pinnipeds, which included a US Department of Agriculture-approved Program of Veterinary Care for the regular collection of blood to monitor health status and to assess apparent health issues. Blood samples were collected periodically from 1989-2007 from males throughout growth and development (e.g., pre- and post-puberty) and females during various reproductive states (e.g., estrous cycle and pregnancy). Blood samples were taken under manual restraint from an interdigital vein in the webbing of the hind flipper using a 20-gauge, $2.54 \mathrm{~cm}$ needle on a $12 \mathrm{cc}$ eccentrictip syringe. Blood from each seal was placed in a $10-\mathrm{ml}$ serum separator tube and processed for clinical chemistry. Remaining serum (1-2 ml) from each seal was transferred to a separate cryo-vial, labeled with seal identification and date, and archived at $-60^{\circ} \mathrm{C}$. $\mathrm{Ar}$ chived serum samples were selected and shipped frozen to a laboratory at New York University School of Medicine (Tuxedo, NY, USA) and stored at $-20^{\circ} \mathrm{C}$ until assay.

Serum samples from adult female fur seals were grouped according to reproductive status: (1) pregnancy (blood collected from 4-12 mo of gestation, $n=13$ samples), (2) post-partum (blood collected from $4 \mathrm{~d}-5$ mo after parturition, $n=8$ samples) and (3) non-pregnancy (blood collected over 12-mo reproductive cycles, $n=6$ samples). Samples from male fur seals were grouped together regardless of age (blood collected from 2 mo-15 yrs, $n=6$ samples). In addition, samples from the pregnancy group were subgrouped according to months of pregnancy: (1) Months 4-5 ( $n=2$ samples), (2) Months 7-8 ( $n=4$ samples) and (3) Months 9-10 ( $n=6$ samples). Month of pregnancy was determined retrospectively from day of parturition. The non-pregnancy group included samples from non-bred and bred seals and was defined according to the absence of a pup after a 12-mo reproductive cycle. Samples that were associated with a known pregnancy that was subsequently lost were not included in the non-pregnancy group. Since there was a limited amount of serum in individual samples, portions of serum were collected from multiple samples within respective groups and combined into separate pools for acid-acetone extraction to isolate a relaxin-containing fraction and test for immuno-reactivity in the validation process.

\subsection{Placental tissue samples}

Northern fur seal, Steller sea lion and harbor seal placentae were collected and made available according to respective permits issued under the US Marine Mammal Protection Act. From the California Marine Mammal Center (Sausalito, CA, USA), a placenta was collected after stillbirth from a stranded Northern fur seal in March 2007 from which a tissue sample was cut and frozen $\left(-80^{\circ} \mathrm{C}\right)$. From the Alaska SeaLife Center (Seward, AK, USA), placentae were 
collected and frozen $\left(-20^{\circ} \mathrm{C}\right)$ after necropsy of a recently deceased free-ranging Steller sea lion and after birth from a captive harbor seal in May 2008. The fur seal placental tissue sample and sea lion and harbor seal placentae were shipped frozen to a laboratory at New York University School of Medicine (Tuxedo, NY, USA) and stored at $-20^{\circ} \mathrm{C}$ until further processing and assay.

Tissue samples from each seal placenta were processed for assay of relaxin in a comparable manner to that described for the spotted hyena placenta (Steinetz et al., 1997). Briefly, a $15 \mathrm{~g}$ sample previously cut from the fur seal placenta, and $250 \mathrm{~g}$ samples cut from a site most representative (darkest red) of the zonary or vascular portion of the sea lion and harbor seal placentae were homogenized in cold phosphate buffered saline (PBS), centrifuged and decanted to remove tissue fragments and fat. Supernatants of the placental tissue samples were set aside for acid-acetone extraction to isolate a relaxin-containing fraction and test for immuno-reactivity in the validation process.

\subsection{Acid-acetone extraction of serum pools and placental tissue supernatants}

Many polypeptides are precipitated by acidified acetone, but relaxin is a relatively small and highly stable protein that is soluble in acid-acetone (Steinetz et al., 1962). Extraction in acidified acetone separates small polypeptides from larger, acetone-insoluble proteins that are predominant in blood and other tissues, which could potentially interfere with immuno-reactivity in the relaxin RIA. The acid-acetone extraction process used herein has been described (Doczi, 1963) and previously used to isolate the relaxincontaining fraction from placental tissue of the spotted hyena to verify immuno-reactivity in the canine relaxin assay (Steinetz et al., 1997). Briefly, serum pooled from pregnant $(2.0 \mathrm{ml})$, nonpregnant $(8.5 \mathrm{ml})$ and male $(7.0 \mathrm{ml})$ fur seals and supernatants of homogenized placental tissue from each seal species were mixed with water, concentrated $\mathrm{HCl}$ and $70 \%(\mathrm{v} / \mathrm{v})$ acetone at $-4{ }^{\circ} \mathrm{C}$ for approximately $24 \mathrm{~h}$. Afterwards, respective mixtures were filtered and precipitated with additional cold acetone (90\%,v/v). Approximately $24 \mathrm{~h}$ later, the acetone supernatants were removed and respective relaxin-containing fractions were dried and reconstituted with assay buffer and set aside until assay.

\subsection{Relaxin assay}

Details of a previously validated canine relaxin RIA have been described (Steinetz et al., 1996). In the present study, 3 antibodies developed against relaxin were initially tested for immuno-reactivity to a relaxin-like substance in raw serum from a pregnant Northern fur seal: (1) rabbit polyclonal porcine relaxin antiserum R6 which reacts specifically with the receptor binding domain of all relaxins thus far sequenced (O'Byrne and Steinetz, 1976), (2) rabbit polyclonal canine relaxin antiserum No. 79888 which is highly reactive with relaxin in canids and felids (Steinetz et al., 1996; de Haas van Dorsser et al., 2006), and (3) rabbit polyclonal canine relaxin antiserum No. 80037 (Steinetz et al., 1996). Specific binding was approximately $12 \%$ with antiserum No. 80037 in pregnant fur seal serum compared to little or no detectable immunoreactivity with the other antisera in the same pregnant fur seal sample. Hence, a homologous canine relaxin RIA was used in the present study which included canine antiserum No. 80037 as the primary antibody (working dilution, 1:5000) and synthetic canine relaxin as reference standard (0.1-12.5 ng/tube) and ${ }^{125}$ I-labeled ligand (approximately $30,000 \mathrm{cpm} /$ tube).

Verification of the canine relaxin RIA for use with serum and placental tissue from Northern fur seals and a Steller sea lion and harbor seal included several validation steps following acid-acetone extraction: (1) isolation and immuno-reactivity of a relaxin- like substance in extracts from pools of pregnant, non-pregnant and male serum and placental tissue from each seal species, (2) specific displacement of radiolabeled canine relaxin from the canine relaxin antibody by increasing volumes (100 and $200 \mu \mathrm{l})$ of extract from pools of pregnant, non-pregnant and male serum and placental tissue from each seal species, and (3) additivity by adding increasing amounts of canine relaxin $(0,0.8$ and $1.6 \mathrm{ng})$ to an extract of pooled male fur seal serum or assay buffer.

Extracts of pooled serum and placental tissue samples from Northern fur seals and a Steller sea lion and harbor seal and raw serum samples from individual fur seals were assayed for immuno-reactive relaxin using 100 or $200 \mu \mathrm{l}$ of extracts in assay buffer or $200 \mu \mathrm{l}$ of raw serum in duplicate. The results were expressed as the average specific binding or concentration of duplicates relative to the canine relaxin reference standard. Assay sensitivity was set at $90 \%$ of specific binding (approximately $0.6 \mathrm{ng} / \mathrm{ml}$ ) and intraand inter-assay coefficients of variation were $5 \%$ and $15 \%$, respectively.

\subsection{Statistical analyses}

Prior to statistical analyses, the data were checked for extreme values using Dixon's outlier test (Kanji, 1993), tested for homogeneity and transformed if necessary. Analysis of variance was used to determine differences in serum concentrations of immuno-reactive relaxin among groups (pregnant, post-partum and non-pregnant and male fur seals) and months of pregnancy (4-5, 7-8, and $9-10)$. If there was a significant effect, independent $t$-tests were used to identify mean differences among groups or months. In serial samples collected repeatedly from the same fur seals before and after parturition, a paired $t$-test was used to compare mean differences in serum relaxin concentrations pre- and post-partum. A probability of $P \leqslant 0.05$ indicated that a difference was significant and probabilities between $P>0.05$ and 0.1 indicated that a difference approached significance. Values are reported as mean \pm SEM unless otherwise indicated.

\section{Results}

Validation results following acid-acetone extraction of pools of serum and placental tissue from Northern fur seals and a Steller sea lion and harbor seal are shown for each step in Table 1. The acid-acetone extraction process with the fur seal placental tissue sample yielded a relaxin-containing fraction that was sufficient to examine duplicate volumes of $100 \mu \mathrm{l}$ but not $200 \mu \mathrm{l}$ of extract (Table 1, Step 2). Compared with $250 \mathrm{~g}$ samples of placental tissue from the sea lion and harbor seal, a $15 \mathrm{~g}$ sample of placental tissue from the fur seal was inadequate to complete the dose-responsive displacement of radiolabeled canine relaxin from the canine antibody.

Mean immuno-reactive relaxin concentrations in raw serum samples from groups of pregnant, post-partum, non-pregnant and male fur seals are shown with statistical results in Table 2. For serial samples collected repeatedly from the same fur seals pre- and post-partum, individual and mean results are shown with statistical results in Table 3. Inspection of the individual results indicated relaxin concentrations declined after parturition in 3 of the 4 seals. In Seal A, the relaxin value during pregnancy in 1989 was uncharacteristically low compared to the concentration at approximately the same stage of gestation in the subsequent year, and in comparison to values in other seals in the pregnant group (Table 3). Consequently, the aberrant value reduced the statistical significance between mean concentrations of relaxin pre- and post-partum.

Mean immuno-reactive relaxin concentrations in fur seals sub-grouped according to months of pregnancy are shown with 
Table 1

Validation steps for verifying a homologous canine relaxin RIA for use in otariids and phocids.

Step 1. Immuno-reactivity in relaxin-containing fractions following acid-acetone extraction of pooled serum and placental tissue from each seal species.

\begin{tabular}{lllll} 
& Relaxin & Non-pregnant pool & Male pool & \\
\cline { 2 - 4 } Acid-acetone extraction & Pregnant pool & 17.2 & Steller sea lion & Harbor seal \\
\hline Fur seal serum $(\mathrm{ng} / \mathrm{ml})$ & 42.7 & 1600 & 292
\end{tabular}

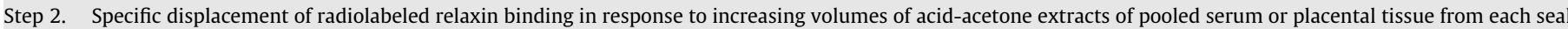
species.

\begin{tabular}{llll} 
Northern fur seal serum & Specific binding (\%) & & Non-pregnant pool \\
\cline { 2 - 3 } $\begin{array}{l}\text { Extract volume }(\mu \mathrm{l}) \\
\text { Pregnant pool }\end{array}$ & 59 & 75 & 61 \\
100 & 44 & & \\
200 & & Steller sea lion & 76 \\
\hline $\begin{array}{l}\text { Placental tissue } \\
\text { Extract volume }(\mu \mathrm{l})\end{array}$ & Northern fur seal & 73 & Harbor seal \\
\hline 100 & 76 & 61 & 87 \\
200 & $*$ & 74
\end{tabular}

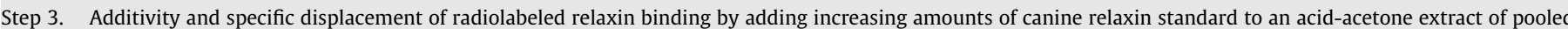
male Northern fur seal serum or assay buffer.

\begin{tabular}{lll} 
& Specific binding $(\%)$ & \\
\cline { 2 - 3 } Canine relaxin $(\mathrm{ng} / \mathrm{ml})$ & Seal serum & Assay buffer \\
\hline 0.0 & 66 & 100 \\
0.8 & 53 & 66 \\
1.6 & 46 & 52
\end{tabular}

* Placental tissue sample ( $15 \mathrm{~g}$ ) was insufficient to prepare an adequate amount of extract for assay at greater volume.

Table 2

Mean $( \pm$ SEM) immuno-reactive relaxin concentrations in raw serum samples grouped according to pregnant, post-partum and non-pregnant females (6) and male (2) Northern fur seals.

\begin{tabular}{lll}
\hline Groups & No. samples & Relaxin $(\mathrm{ng} / \mathrm{ml})^{1}$ \\
\hline Pregnant & 13 & $8.2 \pm 1.5^{\mathrm{a}}$ \\
Post-partum & 8 & $3.6 \pm 1.0^{\mathrm{b}}$ \\
Non-pregnant & 6 & $2.5 \pm 0.4^{\mathrm{b}}$ \\
Male & 6 & $1.1 \pm 0.2^{\mathrm{c}}$ \\
\hline
\end{tabular}

${ }^{1}$ Group effect, $P<0.002$.

a,b,c Values differ, $P<0.05$.

Table 3

Individual and mean concentrations of immuno-reactive relaxin in raw serum from Northern fur seals pre- and post-partum for two consecutive reproductive cycles for Seal A and one reproductive cycle each for Seals B and C.

\begin{tabular}{|c|c|c|c|c|c|}
\hline \multirow[b]{2}{*}{ Seal } & \multirow[b]{2}{*}{$\mathrm{Yr}$} & \multicolumn{2}{|c|}{ Pre-partum } & \multicolumn{2}{|c|}{ Post-partum } \\
\hline & & Time & Relaxin (ng/ml) & Time & Relaxin (ng/ml) \\
\hline A & 1989 & $4 \mathrm{mo}$ & 3.7 & $1 \mathrm{mo}$ & 5.1 \\
\hline A & 1990 & $5 \mathrm{mo}$ & 12.1 & $1 \mathrm{mo}$ & 4.2 \\
\hline B & 1989 & $4 \mathrm{mo}$ & 7.4 & $4 \mathrm{~d}$ & 2.3 \\
\hline $\mathrm{C}$ & 1990 & $3 \mathrm{mo}$ & 10.1 & $5 \mathrm{mo}$ & 0.8 \\
\hline \multicolumn{2}{|c|}{ Mean \pm SEM } & & $8.4 \pm 1.8^{\mathrm{a}}$ & & $3.1 \pm 1.0^{\mathrm{b}}$ \\
\hline
\end{tabular}

a,b Values differ, $P<0.06$.

statistical results in Table 4. Although there was a significant effect of month as a result of a progressive increase in mean concentrations of relaxin during gestation, the data should be interpreted cautiously because of the small number of samples and concentrations that were near the sensitivity of the assay, especially during Months 4-5.

\section{Discussion}

The availability of archived serum samples collected from captive Northern fur seals and placental tissue from a free-ranging

\section{Table 4}

Mean $( \pm$ SEM) immuno-reactive relaxin concentrations in raw serum samples from pregnant Northern fur seals (6) sub-grouped according to month of pregnancy. Month of pregnancy was determined retrospectively from day of parturition.

\begin{tabular}{llll}
\hline Serum sample & \multicolumn{3}{l}{ Months of pregnancy } \\
\cline { 2 - 4 } & $4-5$ & $7-8$ & $9-10$ \\
\hline Number & 2 & 4 & 6 \\
Relaxin $(\mathrm{ng} / \mathrm{ml})^{1}$ & $0.8 \pm 0.0^{\mathrm{a}}$ & $7.1 \pm 1.8^{\mathrm{b}, \mathrm{x}}$ & $11.1 \pm 2.1^{\mathrm{b}, \mathrm{y}}$ \\
\hline
\end{tabular}

${ }^{1}$ Month effect, $P<0.05$.

a,b Values differ, $P<0.04$.

${ }^{\mathrm{x}, \mathrm{y}}$ Values differ, $P<0.1$.

Northern fur seal, Steller sea lion, and captive harbor seal provided the opportunity to adapt and validate a homologous canine relaxin RIA for the discovery of a relaxin-like substance in pinnipeds. The pelagic nature of fur seals (Atkinson, 1997; Boyd et al., 1999) and regulatory criteria under the Marine Mammal Protection Act (NMFS, 2007) preclude systematic collection of blood samples from free-ranging seal pups, juveniles and adults during growth and reproduction. Aquariums have played a historic role in the conservation of fur seals, and periodic collection of blood samples is a routine part of management practices. Even though the number of captive fur seals that have been conditioned for the collection of blood is limited to a few seals and aquariums (e.g., Mystic, CT and Seattle, WA, USA), availability of numerous serum samples archived over multiple years can provide a reasonable distribution of samples for examination during pre- and post-puberty and various stages of the estrous cycle, pregnancy and post-partum. Although the effect of long-term cryopreservation on serum concentrations of relaxin is unknown, it is known that relaxin is a stable and soluble protein hormone in acid-acetone that can withstand exposure to extreme cold, heat and long periods at ambient temperature (Steinetz et al., 1962; Doczi, 1963). In the present study, freezer storage times and conditions were similar among archived pregnant, non-pregnant, and male fur seal 
samples; therefore, any alteration (i.e., decline) in serum relaxin concentrations due to prolonged storage would presumably be proportional among samples. Thus, this study represents an unprecedented collaboration among a diverse group of scientists from government, academia and aquatic institutes to develop a comprehensive data base for reproductive hormones in Northern fur seals that may serve as a future source of reference for samples taken from captive as well as free-ranging fur seals and other otariids and phocids.

The canine relaxin RIA has been fully validated for use in dogs (Steinetz et al., 1996) and successfully validated and adapted for use in a variety of wildlife species primarily as a noninvasive approach to distinguish pregnant from non-pregnant or pseudopregnant animals (Steinetz et al., 2005, 2009). In the present study, acid-acetone extraction (Doczi, 1963; Steinetz et al., 1997) was used to isolate a relaxin-like substance in pools of serum from female (pregnant and non-pregnant) and male Northern fur seals and placental tissue from a Northern fur seal, Steller sea lion and harbor seal. Assay of the relaxin-containing fractions indicated relatively high, intermediate and low serum concentrations of immuno-reactive relaxin in pregnant, non-pregnant and male fur seals, respectively. Immuno-reactive relaxin was also detected in the placenta of each seal species. There was a dose-responsive displacement of radiolabeled canine relaxin from the canine antibody as increasing volumes of extracts from respective serum pools or placental tissue were introduced into the assay. A dose-responsive displacement of radiolabeled canine relaxin was also observed as increasing amounts of the canine relaxin reference standard were added to the relaxin-containing fraction of male fur seal serum. When compared with the same amount of canine relaxin added to assay buffer, specific binding was lower (12-34\%) for the extract than buffer at each level, which was attributed to the additive effect of a relaxin-like substance in male seal serum.

Although the acid-acetone extraction process was inefficient requiring a relatively large volume $(2-8 \mathrm{ml})$ of pooled serum from individual samples from pregnant, non-pregnant and male Northern fur seals, the process was effective and fundamental for validation of the canine relaxin assay for use with fur seal serum. It was not thoroughly known beforehand if components of raw serum would interfere with immuno-reactivity in the relaxin assay. Nevertheless, the extraction process was not practical for the relatively small volume of serum remaining in individual fur seal samples.

In raw serum samples, mean concentrations of immuno-reactive relaxin were significantly higher in pregnant than in non-pregnant or post-partum fur seals, and significantly lower in males than females. Temporally, there was a progressive increase in mean concentrations of relaxin from relatively low values during Months 4-5 to significantly higher values during Months 9-10. In serial samples collected from the same fur seals before and after parturition, mean relaxin concentrations were higher pre-partum than post-partum. The directional changes in serum relaxin from relatively high concentrations during pregnancy to low concentrations after parturition and during non-pregnancy in fur seals is similar to that reported in dogs (Johnston et al., 2001), horses (Ginther, 1992), pigs (Dlamini et al., 1995), laboratory rodents (Sherwood, 1994), camelids (Bravo et al., 1996) and wild animal species (Steinetz et al., $2005,2009)$. Taken together, raw serum from pregnant, non-pregnant (post-partum) and male fur seals did not appear to interfere with detection of relaxin based on comparable relative changes among extracts of pooled serum from corresponding groups in the validation process. Moreover, the combined results supported the hypothesis that immuno-reactive relaxin concentrations are higher in pregnant than in non-pregnant Northern fur seals.

In the present study, the relatively low serum concentrations of immuno-reactive relaxin during Months 4-5 of pregnancy corresponds to the end of embryonic diapause, a period of delayed implantation that reportedly ranges from 3-5 months in Northern fur seals (Daniel, 1981; Boyd, 1991; Atkinson, 1997; Boyd et al., 1999) following ovulation primarily in July (Craig, 1964). However, the lack of samples during diapause and small number of samples thereafter preclude a detailed understanding of any temporal relationship between relaxin and the peri-implantation period in fur seals at this time. Later, during pregnancy, serum concentrations of relaxin were relatively higher and apparently of placental origin. Although low, the source of relaxin in non-pregnant and male fur seals is not known. In species other than pinnipeds, reproductive (e.g., ovaries, uterus, mammary glands, testes, prostate) and nonreproductive organs (e.g., brain, heart, kidneys) have been identified as non-placental sources of relaxin (Hayes, 2004; Sherwood, 2004; Park et al., 2005). Future studies are needed to critically examine the changes in circulating concentrations of relaxin encompassing the end of embryonic diapause and identify and confirm placental and non-placental sources of relaxin in female and male Northern fur seals and other otariids and phocids of both genders

Knowledge of relative changes in circulating concentrations of relaxin has both basic and applied implications. From a basic perspective, results of immunoassay of relaxin in combination with results from ultrasonic imaging of the uterus, conceptus and ovaries in pinnipeds (Adams et al., 2007) can further our understanding of functional and structural relationships at the end of embryonic diapause and survival of the early embryo during implantation in a nonlethal manner. From an applied perspective, assay of relaxin may be a more effective hormonal indicator than progesterone to distinguish between pregnant and non-pregnant or pseudopregnant otariids and phocids. In general, it is thought that the corpus luteum in pregnant seals is maintained throughout gestation, but may regress before parturition in some species of pinnipeds (Daniel, 1981; Boyd, 1991; Atkinson, 1997; Boyd et al., 1999). Comparatively, in non-pregnant seals, it is thought that functional and structural development of the corpus luteum is similar to that during the period of delayed implantation but, thereafter, it gradually regresses in the absence of placental luteotrophic support (Boyd et al., 1999). The condition of elevated concentrations of progesterone in non-pregnant seals that appears to mimic the condition in pregnant seals has been referred to as pseudopregnancy (Atkinson, 1997; Boyd et al., 1999), which seems comparable to the condition reported in dogs (Johnston et al., 2001). Until functional and structural development of the corpus luteum has been thoroughly characterized in pregnant and non-pregnant pinnipeds, the results of immunoassay of circulating concentrations of progesterone as a hormonal indicator of pregnancy will be equivocal. Alternatively, results of the present study indicate that elevated concentrations of immuno-reactive relaxin are pregnancy-specific; hence, relaxin has the potential to serve as an effective hormonal marker for diagnosing pregnancy in otariids and phocids as it is in canids and other species (Steinetz et al., 2005, 2009).

In conclusion, validation of a homologous canine relaxin RIA for use in otariids and phocids resulted in the discovery of a relaxinlike substance in extracted and raw serum and placental tissue from Northern fur seals, a Steller sea lion and harbor seal. Distinctly higher immuno-reactive concentrations during pregnancy indicated the potential for relaxin to serve as a hormonal marker to differentiate between pregnant and non-pregnant or pseudopregnant pinnipeds.

\section{Acknowledgments}

This study was supported, in part, with funds from the National Marine Mammal Laboratory, Seattle, WA and Alaska SeaLife Center's Pinniped Research Program, Seward, AK and is Contribution Number 184 of the Sea Research Foundation, Mystic, CT. The 
authors would like to thank Gayle Sirpenski of Mystic Aquarium for the Northern fur seal serum samples, Liz Wheeler of the California Marine Mammal Center for the Northern fur seal placental sample, Jacqueline Ramsay of the University of Alaska and Alaska SeaLife Center for the Steller sea lion and harbor seal placentae, and Sally Lasano of NYU School of Medicine for technical assistance in conducting the relaxin assays. Portions of the results reported herein have been presented previously (Bergfelt et al., 2008; Steinetz et al., 2009).

\section{References}

Adams, G.P., Testa, J.W., Goertz, C.E.C., Ream, R.R., Sterling, J.T., 2007. Ultrasonographic characterization of reproductive anatomy and early embryonic detection in the Northern fur seal (Callorhinus ursinus) in the field. Mar. Mammal Sci. 23, 445-452.

Atkinson, S., 1997. Reproductive biology of seals. Rev. Reprod. 2, 175-194.

Bergfelt, D.R., Steinetz, B.G., Testa, J.W., Adams, G.P., 2008. Relaxin: a potential hormonal marker of pregnancy in Northern fur seals (Callorhinus ursinus). In: Association of Zoos and Aquariums 84th Annual Conference, Milwaukee, Wisconsin, USA (http://www.aza.org/AZAPublications/ConfPro/index.html).

Boyd, I.L., 1991. Environmental and physiological factors controlling the reproductive cycles in pinnipeds. Can. J. Zool. 69, 1135-1148.

Boyd, I.L., Lockyer, C., Marsh, H., 1999. Reproduction in marine mammals. In: Reynolds, J.E., III, Rommel, S.A. (Eds.), Biology of Marine Mammals. Smithsonian Institution Press, Washington, DC, pp. 218-286.

Bravo, P.W., Stewart, D.R., Lasley, B.L., Fowler, M.E., 1996. Hormonal indicators of pregnancy in llamas and alpacas. J. Amer. Vet. Med. Assoc. 208, 2027-2030.

Carlson, D.A., Gese, E.M., 2007. Relaxin as a diagnostic tool for pregnancy in the coyote (Canis latrans). Anim. Reprod. Sci. 101, 304-312.

Craig, A.M., 1964. Histology of reproduction and the estrus cycle in the female fur seal (Callorhinus ursinus). J. Fish. Res. Board Can. 21, 773-811.

Cross, J.C., Werb, Z., Fisher, S.J., 1994. Implantation and the placenta: key pieces of the development puzzle. Science 266, 1508-1518.

Daniel, J.C., 1981. Delayed implantation in the Northern fur seal (Callorhinus ursinus) and other pinnipeds. J. Reprod. Fert. Suppl. 29, 35-50.

de Haas van Dorsser, F.J., Swanson, W.f., Lasano, S., Steinetz, B.G., 2006. Development, validation, and application of a urinary relaxin radioimmunoassay for the diagnosis and monitoring of pregnancy in felids. Biol. Reprod. 74, 1090-1095.

Dlamini, B.J., Li, Y., Klindt, J., Anderson, L.L., 1995. Acute shifts in relaxin, progesterone, prolactin and growth hormone secretion in Chinese meishan gilts during late pregnancy and after hysterectomy. J. Anim. Sci. 73, 3732.

Doczi, J., 1963. Process for the extraction and purification of relaxin. US Patent $3,096,246$

Dschietzig, T., Stangl, K., 2003. Relaxin: a pregnancy hormone as central player of body fluid and circulation homeostasis. Cell. Mol. Life Sci. 60, 688-700.

Einspanier, A., Nubbemeyer, R., Schlote, S., Schumacher, M., Ivell, R., Fuhrmann, K. Marten, A., 1999. Relaxin in the marmoset monkey: secretion pattern in the ovarian cycle and early pregnancy. Biol. Reprod. 61, 512-520.

Gales, N.J., Williamson, P., Higgins, L.V., Blackberry, M.A., James, I., 1997. Evidence for a prolonged postimplantation period in the Australian sea lion (Neophoca cinerea). J. Reprod. Fertil. 111, 159-163.

Ginther, O.J., 1992. In: Ginther, O.J. (Ed.), Reproductive Biology of the Mare: Basic and Applied Aspects, Equiservices, Cross Plaines, Wisconsin, pp. 195-207.

Greig, D.J., Mashburn, K.L., Rutishauser, M., Gulland, F.M.D., Willliams, T.M., Atkinson, S., 2007. Seasonal changes in circulating progesterone and estrogen concentrations in the California sea lion (Zalophus californianus). J. Mammal. 88, $67-72$.
Harrison, R.J., Harrison Matthews, L., Roberts, J.M., 1952. Reproduction in some pinnipedia. Trans. Zool. Soc. Lond. 27, 437-540.

Hayes, E.S., 2004. Biology of primate relaxin: a paracrine signal in early pregnancy. Reprod. Biol. Endocr. 2, 36-57.

Johnston, S.D., Kustritz, M.V.R., Olson, P.N.S., 2001. Canine pregnancy. In: Johnston, S.D., Kustritz, M.V.R., Olson, P.N.S. (Eds.), Canine and Feline Theriogenology. W.B. Saunders Company, Philadelphia, pp. 66-104.

Kanji, G.K., 1993. Statistical Tests, vol. 45. Sage Publications, London, England, p. 171

King, W.A., 1991. Embryo-mediated pregnancy failure in cattle. Can. Vet. J. 32, 99103.

Miglino, M.A., Ambrosio, C.E., Martins, D.S., Wenceslau, C.V., Pfarrer, C., Leiser, R., 2006. The carnivore pregnancy: the development of the embryo and fetal membranes. Theriogenology 66, 1699-1702.

National Marine Fisheries Service, 2007. Conservation Plan for the Eastern Pacific stock of Northern fur Seals (Callorhinus ursinus). National Marine Fisheries Service, Juneau, Alaska. http://www.fakr.noaa.gov/protectedresources/seals/ fur/cplan/final1207.pdf

O’Byrne, E., Steinetz, B., 1976. Radioimmunoassay (RIA) of relaxin in sera of various species using an antiserum to porcine relaxin. Proc. Soc. Exper. Biol. Med. 152, 272-276.

Park, J.I., Chang, C.L., Hsu, S.Y.T., 2005. New insights into biological roles of relaxin and relaxin-related peptides. Rev. Endocr. Metabol. Dis. 6, 291-296.

Roberts, R.M., Cross, J.C., Learnan, D.W., 1992. Interferons as hormones of pregnancy. Endocr. Rev. 13, 432.

Roberts, R.M., Farin, C.E., Cross, J.C., 1990. Trophoblast proteins and maternal recognition of pregnancy. Oxf. Rev. Reprod. Biol. 12, 147-180.

Sherwood, O.D., 1994. Relaxin. In: Knobil, E., Neill, J.D. (Eds.), The Physiology of Reproduction. Raven Press, NY, pp. 861-1009.

Sherwood, O.D., 2004. Relaxin's physiological roles and other diverse actions. Endocr. Rev. 25, 205-234.

Steinetz, B.G., Beach, V.L., Kroc, R.L., 1962. Relaxin. In: Dorfman, R.I. (Ed.), Methods in Hormone Research VII. Bioassay, Academic Press, NY, pp. 559589.

Steinetz, B.G., Brown, J.L., Roth, T.L., Czekala, N., 2005. Relaxin concentrations in serum and urine of endangered species: correlations with physiologic events and use as a marker of pregnancy. Ann. NY Acad. Sci. 1041, 367378.

Steinetz, B.G., Bullesbach, E.E., Goldsmith, L.T., Schwabe, C., Lust, G., 1996. Use of synthetic canine relaxin to develop a rapid homologous radioimmunoassay. Biol. Reprod. 54, 1252-1260.

Steinetz, B.G., Goldsmith, L.T., Harvey, H.J., Lust, G., 1989. Serum relaxin and progesterone concentrations in pregnant, pseudopregnant, and ovariectomized progestin-treated pregnant bitches: detection of relaxin as a marker of pregnancy. Am. J. Vet. Res. 50, 68-71.

Steinetz, B., Lasano, S., de Haas van Dorsser, F., Glickman, S., Bergfelt, D., Santymire R., Songsassen, N., Swanson, W., 2009. Relaxin concentrations in serum and urine of endangered and crazy mixed-up species: New methods, uses and findings. Ann. NY Acad. Sci. 1160, 179-185.

Steinetz, B.G., Randolph, C., Weldele, M., Frank, L.G., Licht, P., Glickman, S.E., 1997. Pattern and source of relaxin in the reproductive cycle of the spotted hyena (Crotuta crocuta). Biol. Reprod. 56, 1301-1306.

Stewart, D.R., Stabenfeldt, G.H., 1985. Relaxin activity in the pregnant cat. Biol. Reprod. 32, 848-854.

Stewart, D.R., Overstreet, J.W., Celniker, A.C., Hess, D.L., Cragun, J.R., Boyers, S.P., Lasley, B.L., 1993. The relationship between hCG and relaxin secretion in normal pregnancies vs peri-implantation spontaneous abortions. Clin. Endocr. (Oxf) 38 379-385.

Villegas-Amtmann, S., Costa, D.P., Atkinson, S., 2009. Low synchrony in the breeding cycle of Galapagos sea lions revealed by seasonal progesterone concentrations. J. Mammal. 90, in press.

York, A.E., Scheffer, V.B., 1997. Timing of implantation in the Northern fur seal, Callorhinus ursinus. J. Mammal. 78, 675-683. 